\title{
PERBANDINGAN HIBRID ULAT SUTERA (Bombyx mori L.) ASAL CINA DENGAN HIBRID LOKAL DI SULAWESI SELATAN
}

\author{
Comparison of Chinese-Origin and Local Silkworm (Bombyx mori L.) \\ Hybrids in South Sulawesi \\ Lincah Andadari ${ }^{1}$ dan/and Kuntadi ${ }^{2)}$ \\ ${ }^{1)}$ Pusat Penelitian dan Pengembangan Produktivitas Hutan \\ Kampus Balitbang Kehutanan, Jl. Gunung Batu 5, Bogor 16118 \\ Telp. (0251) 8631238, Fax. (0251) 7520005 \\ ${ }^{2)}$ Pusat Penelitian dan Pengembangan Konservasi dan Rehabilitasi \\ Kampus Balitbang Kehutanan, Jl. Gunung Batu 5 Kotak Pos 165, Bogor 16118 \\ Telp. (0251) 8633234, Fax. (0251) 8638111
}

Naskah masuk : 26 September 2013; Naskah diterima : 29 September 2014

\begin{abstract}
The quality of Chinese-origin silkworm hybrid was evaluated by means of comparison its various parameters to local commercial hybrid produced by Perhutani.company. This study aims to assess its performances as an alternate source of silkworm line. The parameters observed were egg hatchability, larval period, cocoon yield, and cocoon quality. Using factorial experiment in a randomized block design with six replications, the two hybrids were reared in two different locations in South Sulawesi, namely Soppeng (100 $\mathrm{m}$ a.s.l.) and Enrekang (800 $\mathrm{m}$ a.s.l.) The result showed that Chinese hybrid has higher egg hatchability, cocoon yield, and filament reelability in both rearing locations. The differences among the two hybrids were about $9 \%$ in hatchability, $13 \%$ in cocoon yield, and $6-9 \%$ in filament reelability. Larva period of Chinese hybrid is two days shorter compared to it of local hybrid. Local hybrid had better quality cocoon and higher normal cocoon.
\end{abstract}

Keywords: Chinese hybrid, Perum Perhutani hybrid, cocoon quality, egg quality, silkworm

\begin{abstract}
ABSTRAK
Uji mutu hibrid ulat sutera asal Cina dilakukan dengan membandingkan beberapa parameter pemeliharaan dengan hibrid lokal produksi Perum Perhutani guna menilai potensinya sebagai hibrid alternatif. Kedua hibrid diuji coba di dua lokasi berbeda di Sulawesi Selatan, yaitu Soppeng (100 m dpl) dan Enrekang $(800 \mathrm{~m} \mathrm{dpl})$, menggunakan rancangan acak kelompok dengan pola faktorial. Parameter yang diamati meliputi persentase penetasan, masa larva, rendemen pemeliharaan dan kualitas kokon. Hasil penelitian menunjukan hibrid Cina menghasilkan persentase daya tetas, rendemen pemeliharaan, dan daya gulung serat sutera yang lebih tinggi daripada hibrid lokal di kedua lokasi pemeliharaan. Perbedaan kedua hibrid sekitar 9\% untuk daya tetas telur, $13 \%$ untuk rendemen pemeliharaan, dan antara 6-9\% untuk daya gulung serat. Hibrid Cina juga memiliki masa larva yang lebih pendek sekitar dua hari dibandingkan hibrid lokal. Sementara hibrid lokal Perhutani menghasilkan kualitas kokon yang lebih baik dari pada hibrid Cina. Hibrid lokal juga menghasilkan persentase jumlah kokon normal yang lebih tinggi.
\end{abstract}

Kata kunci: Hibrid Cina, hibrid Perum Perhutani, kualitas kokon, kualitas telur, ulat sutera

\section{PENDAHULUAN}

Keberhasilan usaha pemeliharaan ulat sutera tergantung kepada beberapa faktor, yaitu pakan, bibit ulat, kondisi pemeliharaan, dan sistem pemeliharaan (Gowda \& Reddy, 2007; Bizhannia \& Seidavi, 2008, dalam Seidavi, 2012). Meskipun di Indonesia kokon dapat dihasilkan sepanjang tahun, namun sampai saat ini jumlah produksi benang sutera masih fluktuatif. Salah satu penyebabnya adalah penggunaan jenis ulat yang sama untuk kondisi pemeliharaan yang beragam. Menurut Hussain et al. (2011a), sifat biologis dan karakter kokon yang dihasilkan dipengaruhi oleh temperatur setempat, musim saat pemeliharaan, dan struktur genetik dari galur ulat sutera. Oleh karena itu beberapa jenis ulat baru yang lebih spesifik untuk masing-masing kondisi pemeliharaan perlu didapatkan.

Kualitas hibrid merupakan aspek penting dalam industri persuteraan karena sering menjadi penyebab kehilangan produksi atau kegagalan. 
Kualitas hibrid yang baik adalah hibrid yang bebas penyakit, mempunyai persentase penetasan yang tinggi, memberikan penetasan yang seragam, dan menghasilkan kokon yang stabil (Saheb \& Gowda, 1987).

Dalam upaya meningkatkan kuantitas dan kualitas telur ulat sutera serta menjamin mutu dan ketersediaan kokon, pemerintah telah menetapkan aturan pengadaan dan peredaraan telur ulat sutera di Indonesia melalui Peraturan Menteri Kehutanan No P-56/Menhut-II/2007tentang Pengadaan dan Peredaran Telur Ulat Sutera. Peraturan ini membuka peluang masuknya hibrid ulat sutera dari luar negeri ke Indonesia secara syah (legal) untuk mendampingi hibrid lokal yang selama ini hanya diberikan ijin produksinya kepada Perum Perhutani. Aspek legalitas sangat diperlukan, selain untuk memberikan kepastian hukum, juga untuk mengatur tertib peredaran dan menjaga mutu hibrid, mengingat hibrid ulat sutera impor, menurut Sadapotto (2010), disinyalir sudah banyak beredar di masyarakat secara ilegal. Permenhut No. P-56/ Menhut-II/2007 mengatur antara lain bahwa hibrid impor harus sudah disertifikasi dari negara asalnya, pemasukannya ke Indonesia melalui proses karantina, dan harus memenuhi persyaratan bermutu baik dan adaptif terhadap lingkungan setempat. Untuk itu, permohonan izin pemasukan telur harus dilengkapi dengan sertifikat yang menerangkan asal usul (certificate of origin), sertifikat kualitas (certificate of quality), dan sertifikat kesehatan (certificate of health) dari negara asal hibrid, serta sertifikat uji adaptasi yang diterbitkan oleh Badan Litbang Kehutanan atau lembaga penelitian lainnya.

Uji adaptasi adalah kegiatan untuk mengkaji kesesuaian jenis ulat terhadap lokasi di mana ulat sutera akan dibudidayakan. Uji tersebut dilakukan secara multilokasi pada kondisi lingkungan yang berlainan atau pada kondisi ekosistem yang dinamis antar tempat dan waktu. Kondisi ideal untuk uji adaptasi yaitu yang mewakili wilayah dengan klimat yang bervariasi atau beberapa lokasi dalam satu wilayah di mana jenis baru direncanakan akan didistribusikan (ESCAP, 1993). Uji adaptasi biasanya dilakukan di stasiun penelitian setempat atau di tempat produksi telur dan didampingi oleh jenis ulat komersial sebagai kontrol.

Tulisan ini disusun berdasarkan hasil penelitian uji perbandingan dua hibrid ulat sutera, yakni hibrid impor asal Cina dan hibrid komersial yang diproduksi di dalam negeri. Penelitian dimaksudkan untuk mendapatkan hibrid ulat sutera berkualitas baik yang akan ditetapkan sebagai hibrid komersial alternatif untuk melengkapi hibrid komersial yang sudah ada.

\section{METODOLOGI}

\section{A. Waktu dan Lokasi Penelitian}

Penelitian dilaksanakan pada bulan Desember tahun 2009 di sentra produksi kokon yang mewakili dua wilayah dengan ketinggian tempat berbeda di Sulawesi Selatan, yakni Soppeng dengan ketinggian tempat $100 \mathrm{~m}$ dpl dan Enrekang dengan ketinggian tempat $800 \mathrm{~m}$ dpl. Ruangan dan alat pemeliharaan ulat di kedua lokasi uji adaptasi dipilih yang bentuk dan kondisinya sama.

\section{B. Bahan dan Alat}

Bahan yang digunakan berupa telur ulat sutera dari dua jenis hibrid bivoltine, yaitu hibrid baru asal Cina (kode persilangan F9X7) dan hibrid komersial atau hibrid lokal hasil produksi Perum Perhutani Soppeng (kode persilangan C301), dan daun murbei (Morus sp.) sebagai pakannya. Hibrid komersial digunakan sebagai kontrol. Hibrid asal Cina diproduksi oleh Guangdong Silk Corp. Group Yingde Egg Production Farm, Cina dan diimpor oleh CV. Masalangka Group. Peralatan berupa cold storage, inkubator, rak pemeliharaan, sasag, alat pengokonan dan lainlain.

\section{Metode Penelitian}

\section{Rancangan penelitian}

Penelitian dilakukan melalui percobaan faktorial dengan dua faktor yang masing-masing terdiri dari dua taraf. Kedua faktor tersebut yaitu jenis hibrid ulat sutera dan ketinggian tempat/ lokasi pemeliharaan. Jenis hibrid terdiri dari hibrid Cina dan hibrid lokal, sedangkan lokasi pemeliharaan yaitu Soppeng (mewakili zonasi < $400 \mathrm{~m} \mathrm{dpl}$ ) dan Enrekang (mewakili zonasi antara 400-800 m dpl). Secara keseluruhan terdapat empat kombinasi perlakukan di dalam percobaan yang dilakukan.

Percobaan dilakukan menggunakan percobaan dua faktor dalam Rancangan Acak Kelompok dengan enam kelompok yang masing-masing terdiri dari empat perlakuan. Pengelompokan didasarkan kepada posisi rak pemeliharaan ulat yang masing-masing bentuknya relatif homogen. Model rancangan menurut Mattjik dan Sumertajaya (2002) adalah:

$$
Y_{i j k}=\mu+\alpha_{i}+\beta_{j}+(\alpha \beta)_{i j}+\rho_{k}+\varepsilon_{i j k}
$$


Keterangan:

$\mathrm{Y}_{\mathrm{ijk}}=$ nilai respon pada faktor jenis hibrid taraf ke $\mathrm{i}$, faktor lokasi taraf ke-j, ulangan ke-k (Yield response on treatments of the $i^{\text {th }}$ factor of hybrid, $j^{\text {th }}$ factor of site, and $k^{\text {th }}$ replication)

Di dalam percobaan, setiap hibrid ulat sutera disediakan sebanyak 0,5 boks telur di masingmasing lokasi. Pemeliharaaan telur hingga mengokon dilakukan dengan standar pemeliharaan yang sama, meliputi tata cara inkubasi telur, penyiapan dan proses disinfeksi ruang pemeliharaan, jenis murbei dan jumlah pakan yang diberikan selama pemeliharaan ulat, pengaturan suhu dan kelembaban ruang ulat, dan perlengkapan pengokonan.

Parameter yang diamati meliputi :

- Kualitas telur (jumlah telur dan persentase penetasan).

- Kualitas ulat (keseragaman pertumbuhan ulat dan rendemen pemeliharaan).

- Kualitas kokon (produksi kokon normal, bobot kokon, bobot kulit kokon, dan persentase kulit kokon).

- Kualitas serat (panjang, persentase, dan ketebalan serat).

\section{Teknik pemeliharaan}

- Telur diletakkan di ruang inkubasi selama 10-12 hari sebelum saat penetasan dengan pengaturan suhu sekitar $25^{\circ} \mathrm{C}$ dan kelembaban $75-80 \%$.

- Pemeliharaan ulat dilakukan di ruang pemeliharaan milik petani setempat. Ulat kecil dibungkus dengan kertas parafin sementara ulat besar diletakkan terbuka pada rak-rak pemeliharaan.

- Pemeliharaan ulat mengikuti teknik standar (Kaomini, 2002) dengan pengaturan yang disesuaikan dengan kondisi setempat. Kebutuhan temperatur dan kelembaban untuk masing-masing instar diupayakan agar mendekati kebutuhan optimum. Pakan diberikan sebanyak tiga kali sehari pada saat ulat kecil (instar I sampai instar III) dengan interval setiap lima jam sekali mulai dari jam 07.00 WIB, sedangkan pada saat ulat besar (instar IV dan V) pemberian makan dilakukan empat kali per hari dengan interval yang sama yaitu limajam.

- Pada awal instar IV dihitung sebanyak 2.000 ekor ulat dari setiap plot percobaan untuk terus dipelihara dan dipertahankan sebagai obyek pengujian selanjutnya.

- Pada hari keenam sampai kedelapan dari instar V ulat-ulat yang sudah siap memasuki masa istirahat diambil satu per satu secara manual untuk dipindahkan ke rak pengokonan.

- Kokon dipanen pada hari kelima dan keenam setelah dikokonkan, dan diseleksi untuk dianalisa guna kepentingan pengukuran sesuai parameter yang diamati di atas.

\section{Analisa data}

Data pengamatan dianalisis mengunakan sidik ragam. Dalam hal hasil sidik ragam menunjukkan beda nyata antar nilai rata-rata, analisis dilanjutkan dengan uji jarak berganda Duncan untuk mengelompokkan perlakuan yang tidak berbeda nyata.

\section{HASIL DAN PEMBAHASAN}

\section{A. Hasil}

Pemeliharaan ulat dilaksanakan di salah satu petani di Kabupaten Soppeng dan Enrekang. Ketinggian tempat dan kondisi lingkungan ke dua lokasi pemeliharaan selama dilakukan uji adaptasi adalah sebagaimana pada Tabel 1. Gambar 1 memperlihatkan suasana ruang pemeliharaan di masing-masing lokasi. Jenis murbei yang terdapat di lokasi yaitu Morus alba var Kanva 2, $M$. cathayana dan $M$. multicaulis yang masingmasing ditanam dalam pola monokultur.

Tabel (Table) 1. Kondisi lingkungan kedua lokasi percobaan(Environmental condition of two study sites)

\begin{tabular}{lcc}
\hline $\begin{array}{l}\text { Karakteristik lokasi } \\
\text { (Site characteristics) }\end{array}$ & Soppeng & Enrekang \\
\hline $\begin{array}{l}\text { Ketinggian tempat (m dpl) } \\
\text { (Altitude) }\end{array}$ & 100 & 800 \\
$\begin{array}{l}\text { Kisaran suhu }\left({ }^{\circ} \mathrm{C}\right) \\
\text { (Temperature) }\end{array}$ & $26-31$ & $22-27$ \\
$\begin{array}{l}\text { Kisaran kelembaban (\%) } \\
\text { (Humidity) }\end{array}$ & $64-83$ & $76-90$ \\
\hline
\end{tabular}




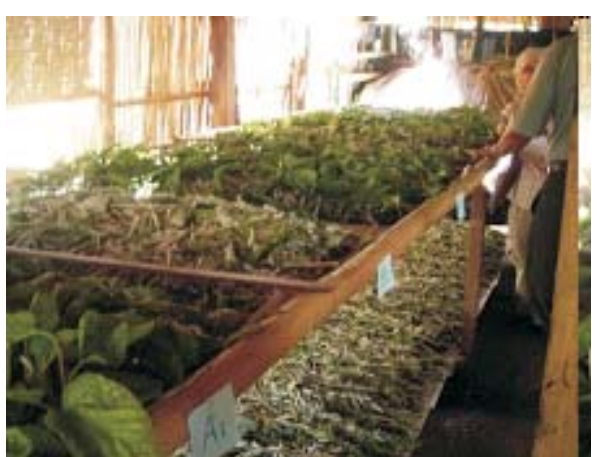

Soppeng

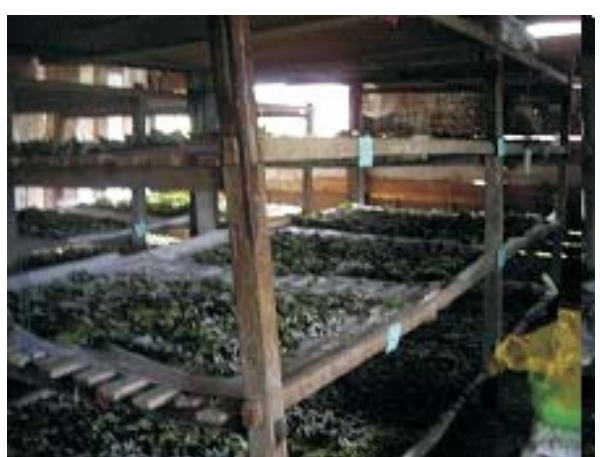

Enrekang

Gambar (Figure) 1. Ruang pemeliharaan ulat sutera di Soppeng dan Enrekang (Silkworm rearing chamber in Soppeng and Enrekang)

\section{Kualitas telur}

Kualitas telur dinilai berdasarkan jumlah telur per box, persentase penetasan, dan masa larva. Tabel 2 memperlihatkan jumlah rata-rata persentase tetas telur, masa larva, dan rendemen pemeliharaan kedua jenis hibrid ulat sutera di kedua lokasi penelitian.

Hasil perhitungan jumlah telur menunjukkan hibrid Cina memiliki jumlah yang lebih banyak dalam setiap box-nya dibanding hibrid lokal asal Perum Perhutani. Jumlah telur per box untuk hibrid Cina dan hibrid lokal masing-masing sebanyak 37.000 telur dan 25.000 telur.

Daya tetas telur kedua hibrid ulat sutera menunjukkan perbedaan yang nyata $(\mathrm{P}<0,05)$. Hibrid Cina memiliki daya tetas yang lebih tinggi dibanding hibrid lokal, baik yang dipelihara di daerah Soppeng maupun di daerah Enrekang. Persentase penetasan telur di lokasi Soppeng untuk hibrid asal Cina rata-rata sebesar 91,10 \pm $1,78 \%$, sedangkan untuk hibrid lokal rata-rata sebesar $81,95 \pm 5,44 \%$. Hasil yang hampir sama diperoleh pada uji coba di Enrekang, daya tetas telur rata-rata sebesar 90,27 $\pm 1,62 \%$ (hibrid Cina) berbanding $81,76 \pm 0,81 \%$ (hibrid lokal). Perbedaan persentase penetasan telur antara hibrid asal Cina dan lokal terlihat cukup besar $( \pm$ $10 \%$ ), baik untuk lokasi Soppeng maupun Enrekang. Selain itu, hibrid Cina memiliki masa larva yang lebih pendek dari pada hibrid lokal. Perbedaan masa larva kedua hibrid berkisar dua hari.

Tabel (Table) 2. Perbandingan persentase tetas telur, masa larva, dan rendemen pemeliharaan ulat sutera hibrid Cina dan hibrid lokal di Soppeng dan Enrekang (Comparative performances of egg hatchability, larval life, and yield of Chinese-origin and local silkworm hibrids in Soppeng and Enrekang)

\begin{tabular}{lccc}
\hline $\begin{array}{c}\text { Perlakuan } \\
\text { (Treatments) }\end{array}$ & $\begin{array}{c}\text { Persentase tetas } \\
(\text { Egg hatchability }(\%))\end{array}$ & $\begin{array}{c}\text { Masa larva } \\
\text { (Larval period) }\end{array}$ & $\begin{array}{c}\text { Rendemen pemeliharaan } \\
(\text { Yield }(\%))\end{array}$ \\
\hline $\begin{array}{l}\text { Soppeng } \\
\text { Hibrid Cina }\end{array}$ & $91,10 \pm 1,78^{\mathrm{a}}$ & 20 hari 7 jam & $92,8 \pm 5,69^{\mathrm{a}}$ \\
Hibrid Lokal & $81,95 \pm 5,44^{\mathrm{b}}$ & 22 hari 8 jam & $79,18 \pm 8,10^{\mathrm{b}}$ \\
Enrekang & & \\
Hibrid Cina & $90,27 \pm 1,62^{\mathrm{a}}$ & 26 hari 7 jam & $93,3 \pm 7,34^{\mathrm{a}}$ \\
Hibrid Lokal & $81,76 \pm 0,81^{\mathrm{b}}$ & 28 hari 4 jam & $89,2 \pm 7,40^{\mathrm{ab}}$ \\
\hline
\end{tabular}

Keterangan (Remarks) : Nilai dalam kolom yang diikuti dengan huruf yang sama berarti tidak berbeda nyata pada taraf $5 \%$ menurut Uji Jarak Berganda Duncan (Value in each column followed by same letter is not significantly different at $5 \%$ Duncan multiple range test) 


\section{Kualitas ulat}

Kualitas ulat seperti rendemen pemeliharaan perlu diperhatikan karena berpengaruh terhadap hasil produksi kokon yang dihasilkan. Data penelitian menunjukkan rata-rata persentase rendemen pemeliharaan yang dapat dihasilkan dari hibrid Cina lebih tinggi dibandingkan hibrid lokal (Tabel 2). Perbedaan yang nyata $(\mathrm{P}<0,05)$ antar kedua hibrid terlihat dari hasil pengujian di Soppeng, di mana perbedaan persentase rendemen pemeliharaannya mencapai angka di atas $10 \%$.

\section{Kualitas kokon}

Hasil analisis kualitas kokon menunjukkan adanya perbedaan yang nyata antar lokasi dan jenis hibrid $(\mathrm{P}<0,01)$. Berdasarkan parameter persentase kokon normal, bobot kokon, bobot kulit kokon, dan persentase kulit kokon, secara keseluruhan kualitas hibrid yang berasal dari Perum Perhutani (hibrid lokal) menunjukkan hasil yang lebih tinggi dibandingkan dengan hibrid dari Cina(Tabel 3).

Tabel(Table) 3. Perbandingan kualitas kokon hibrid Cina dan hibrid lokal di Soppeng dan Enrekang (Performances comparation of cocoon quality of Chinese-origin and local silkworm hybrids in Soppeng and Enrekang)

\begin{tabular}{|c|c|c|c|c|}
\hline $\begin{array}{l}\text { Perlakuan } \\
\text { Treatments }\end{array}$ & $\begin{array}{c}\text { Kokon normal } \\
(\text { Normal cocoon) } \\
(\%)\end{array}$ & $\begin{array}{l}\text { Bobot kokon } \\
\text { (Cocoon weight) } \\
(\mathrm{g})\end{array}$ & $\begin{array}{c}\text { Bobot kulit kokon } \\
\text { (Cocoon shell } \\
\text { weight })(\mathrm{g})\end{array}$ & $\begin{array}{l}\text { Persentase kulit } \\
\text { kokon (Cocoon } \\
\text { shell ratio) }(\%)\end{array}$ \\
\hline \multicolumn{5}{|l|}{ Soppeng } \\
\hline Hibrid Cina & $90,08 \pm 3,69^{\mathrm{ab}}$ & $1,44 \pm 0,09^{\mathrm{d}}$ & $0,30 \pm 0,01^{\mathrm{c}}$ & $20,96 \pm 0,31^{\mathrm{c}}$ \\
\hline Hibrid Lokal & $86,75 \pm 5,23^{b}$ & $1,70 \pm 0,05^{\mathrm{b}}$ & $0,41 \pm 0,02^{\mathrm{b}}$ & $23,97 \pm 0,69^{\mathrm{a}}$ \\
\hline \multicolumn{5}{|l|}{ Enrekang } \\
\hline Hibrid Cina & $80,08 \pm 1,50^{\mathrm{c}}$ & $1,57 \pm 0,03^{\mathrm{c}}$ & $0,32 \pm 0,01^{\mathrm{c}}$ & $20,58 \pm 0,23^{\mathrm{c}}$ \\
\hline Hibrid Lokal & $93,25 \pm 3,36^{\mathrm{a}}$ & $2,04 \pm 0,06^{\mathrm{a}}$ & $0,46 \pm 0,02^{\mathrm{a}}$ & $22,94 \pm 0,30^{\mathrm{b}}$ \\
\hline
\end{tabular}

Keterangan (Remarks) : Nilai dalam kolom yang diikuti dengan huruf yang sama berarti tidak berbeda nyata pada taraf $5 \%$ menurut Uji Jarak Berganda Duncan (Value in each column followed by same letter is not significantly different at $5 \%$ Duncan multiple range test)

a. Kokon normal

Hasil sidik ragam (Anova) pada parameter kokon normal menunjukkan perbedaan yang nyata pada taraf 5\%. Hibrid Cina menghasilkan persentase kokon normal yang lebih tinggi hanya di daerah Soppeng, sedangkan hibrid lokal dapat menghasilkan persentase kokon normal yang lebih tinggi di kedua daerah.

b. Bobotkokon

Bobot kokon dari hibrid lokal di kedua lokasi menunjukkan hasil yang lebih baik dibanding dengan hibrid dari Cina. Bobot kokon yang dihasilkan dari hibrid lokal masih berada pada kisaran rata-rata bobot kokon hibrid (FI) di daerah tropis, yang menurut Mah (1998) berkisar 1,5-2,0 g, sedangkan rata-rata bobot kokon dari hibrid asal Cina untuk pemeliharaan di Enrekang yang didukung dengan kondisi lingkungan yang optimum hanya berada di batas bawah, yaitu sebesar 1,57 g. Pada pemeliharaan di Soppeng, bobot kokon dari hibrid Cina bahkan di batas bawah kisaran bobot kokon yang disebutkan Mah (1998).

c. Bobot kulitkokon

Analisis ragam untuk bobot kulit kokon menunjukkan bahwa perbedaan yang nyata $(\mathrm{P}<0,01)$ antara jenis hibrid dan lokasi. Pemeliharaan di Enrekang menghasilkan bobot kokon yang lebih tinggi dibandingkan pemeliharaan di Soppeng, terutama untuk hibrid lokal. Di kedua lokasi pemeliharaan, hibrid lokal memperlihatkan hasil yang lebih baik daripada hibrid asal Cina dengan perbedaan yang sangat nyata. Bobot kulit kokon yang lebih tinggi secara ekonomis lebih menguntungkan karena semakin besar kandungan suteranya.

d. Persentase kulit kokon

Besarnya nilai persentase kulit kokon sangat ditentukan oleh berat kokon dan berat kulit kokon. Persentase kulit kokon tersebut dapat meng- 
gambarkan persentase serat kasar yang dapat diperoleh dari hasil panen.

Persentase kulit kokon selama penelitian dapat dilihat pada Tabel 3. Analisis ragam persentase kulit kokon menunjukkan perbedaan yang nyata $(\mathrm{P}<0,01)$ antara jenis hibrid dan lokasi.

\section{Kualitas serat}

Tabel 4 memperlihatkan perbandingan kualitas serat yang dihasilkan dari hibrid Cina dan hibrid lokal yang dipelihara di dua lokasi dengan ketinggian tempat berbeda.

Tabel(Table) 4. Perbandingan kualitas serat hibrid Cina dan hibrid lokal di Soppeng dan Enrekang (Comparative performances of filament quality of Chinese-origin and local silkworm hibrids in Soppeng and Enrekang)

\begin{tabular}{|c|c|c|c|c|c|}
\hline $\begin{array}{l}\text { Perlakuan } \\
\text { Treatments }\end{array}$ & $\begin{array}{l}\text { Panjang serat } \\
\text { (Filament } \\
\text { length }(\mathrm{m}))\end{array}$ & $\begin{array}{c}\text { Persentase serat } \\
(\text { Filament } \\
\text { percentage }(\%))\end{array}$ & $\begin{array}{l}\text { Tebal dinier } \\
\text { (Dinier } \\
\text { thickness) }\end{array}$ & $\begin{array}{l}\text { Daya gulung } \\
\text { (Reelability) }\end{array}$ & $\begin{array}{c}\text { Bobot } \\
\text { benang/50 } \\
\text { kokon } \\
\text { (Thread } \\
\text { weight } / 50 \\
\text { cocoon) }\end{array}$ \\
\hline \multicolumn{6}{|l|}{ Soppeng } \\
\hline Hibrid Cina & $994,84 \pm 45,27^{b}$ & $17,91 \pm 0,59^{\mathrm{c}}$ & $2,37 \pm 0,09^{\mathrm{d}}$ & $95,56 \pm 5,34^{\mathrm{a}}$ & $8,87 \pm 0,84^{\mathrm{b}}$ \\
\hline Hibrid Lokal & $1127,83 \pm 8,63^{\mathrm{a}}$ & $21,24 \pm 0,81^{\mathrm{a}}$ & $2,71 \pm 0,18^{\mathrm{c}}$ & $89,58 \pm 7,33^{\mathrm{a}}$ & $9,51 \pm 1,89^{b}$ \\
\hline \multicolumn{6}{|l|}{ Enrekang } \\
\hline Hibrid Cina & $889,08 \pm 39,24^{c}$ & $19,14 \pm 0,39^{b}$ & $2,97 \pm 0,14^{b}$ & $85,57 \pm 10,47^{\mathrm{ab}}$ & $10,73 \pm 0,44^{b}$ \\
\hline Hibrid Lokal & $1026,05 \pm 0,42^{\mathrm{a}}$ & $21,49 \pm 0,99^{\mathrm{a}}$ & $3,63 \pm 0,12^{\mathrm{a}}$ & $76,11 \pm 8,30^{\mathrm{b}}$ & $13,66 \pm 1,86^{\mathrm{a}}$ \\
\hline
\end{tabular}

Keterangan(Remarks): Nilai dalam kolom yang diikuti dengan huruf yang sama berarti tidak berbeda nyata pada taraf $5 \%$ menurut Uji Jarak Berganda Duncan. (Value in each column followed by same letter is not significantly different at $5 \%$ Duncan multiple range test).

\section{a. Panjang serat}

Analisis ragam untuk panjang serat menunjukkan perbedaan yang nyata $(\mathrm{P}<0,01)$. Terdapat perbedaan pada rata-rata panjang serat antar hibrid dan antara lokasi pemeliharaan. Hibrid lokal di kedua lokasi pemeliharaan menghasilkan panjang serat yang lebih tinggi dibandingkan hibrid Cina, yaitu rata-rata sepanjang 1076,94 $\mathrm{m}$ berbanding 941,96 m (hasil rata-rata jenis hibrid di dua lokasi). Pemeliharaan di Soppeng, baik untuk hibrid lokal maupun hibrid Cina, menghasilkan rata-rata panjang serat yang lebih tinggi dari pada pemeliharaan di Enrekang.

\section{b. Persentase serat}

Ada korelasi positif antara panjang serat dengan persentase serat. Semakin besar persentase serat maka panjang serat semakin tinggi. Di Korea, panjang serat umumnya berkisar antara $800-1000 \mathrm{~m}$ pada musim semi dan $600-900 \mathrm{~m}$ pada musim panas dan gugur (Choe, n.d). Dalam percobaan ini, kedua hibrid menunjukkan panjang serat yang cukup baik, berkisar antara 850 sampai $1.100 \mathrm{~m}$. Hibrid lokal cenderung lebih baik ha- silnya daripada hibrid impor Cina dengan ratarata di atas $1000 \mathrm{~m}$ panjang seratnya. Menurut Atmosoedardjo et al. (2000), panjang serat dipengaruhi oleh persilangan ras ulat sutera.

c. Daya gulung (Reelability)

Daya gulung hibrid Cina di kedua tempat pada ketinggian yang berbeda cenderung menunjukkan hasil yang lebih baik, yaitu lebih dari $85 \%$.

d. Bobot benang per 50 kokon

Persentase bobot serat merupakan persentase berat serat yang diperoleh dari sebuah kokon. Persentase bobot serat dipengaruhi oleh ras ulat sutera, mutu dan pemberian pakan (Samsijah \& Andadari 1993). Selain itu, persentase bobot serat dapat dipengaruhi oleh alat pintal yang digunakan, kondisi pemeliharaan dan waktu pengokonan (Budisantoso, 1997).

Analisis ragam untuk bobot benang menunjukkan perbedaan yang nyata $(\mathrm{P}<0,01)$. Bobot benang per 50 kokon hibrid lokal yang dipelihara di Enrekang menghasilkan nilai yang tertinggi, yaitu 13,66, sedangkan ketiga perlakuan yang lain menunjukkan hasil yang tidak berbeda yang 
nyata. Hasil ini sejalan dengan bobot kokon dan persentase kulit kokon serta persentase serat.

\section{B. Pembahasan}

Keseragaman penetasan dan persentase penetasan yang tinggi merupakan hal yang sangat utama dalam usaha budidaya ulat sutera. Kedua parameter ini sering dijadikan tolok ukur kualitas hibrid, meskipunkeberhasilannya akan dicapai jika didukung oleh sistem penetasan dan penanganan telur yang sesuai dengan ketentuan. Penelitian Nezhad et al. (2010) menunjukkan faktor galur sangat menentukan tingkat reproduktifitas ulat sutera, sementara penelitian Hussain et al. (2011b) yang menguji beberapa galur murni pada berbagai kondisi temperatur dan kelembaban udara menunjukkan bahwa faktor biofisik sangat berpengaruh terhadap produksi dan daya tetas telur. Daya tetas tertinggi, menurut Husein et al. (2011a), yaitu pada suhu $\pm 25^{\circ} \mathrm{C}$ dan kelembaban udara antara $70-80 \%$. Mengingat dalam penelitian ini kedua hibrid ulat sutera dipelihara pada kondisi biofisik yang sama dengan temperatur dan kelembaban udara yang diatur pada kondisi optimum untuk pemeliharaan ulat sutera, maka, berdasarkan parameter daya tetas telur, hibrid asal Cina memiliki kualitas yang lebih baik daripada hibrid lokal. Masa larva hibrid Cina yang lebih pendek memberi keuntungan bagi petani karena akan mengurangi volume pakan yang harus disediakan.

Hussain et al. (2011a), mengutip beberapa laporan penelitian, mengemukakan bahwa ulat sutera instar IV dan V sangat sensitif terhadap temperatur yang tinggi. Perubahan kondisi lingkungan berikut sistem pengelolaan yang kurang baik dapat menghasilkan rendemen pemeliharaan yang rendah akibat tingginya mortalitas larva. Mortalitas juga bisa disebabkan oleh penyakit. Tandatanda kematian larva akibat penyakit ditemukan selama penelitian berlangsung, yaitu berwarna hitam (gosong) dan lembek. Menurut Atmosoedardjo et al. (2000), larva yang mati pada saat mengokon dengan tanda-tanda seperti ini dapat disebabkan oleh penyakit grasserie (NPV).

Hasil penelitian menunjukkan hibrid Cina memiliki daya adaptasi yang lebih tinggi dari hibrid lokal. Pada kondisi lingkungan dengan temperatur yang kurang optimum seperti di Soppeng, rendemen pemeliharaan hibrid Cina jauh di atas rendemen hibrid lokal dengan perbedaan lebih dari $10 \%$. Demikian halnya pada pemeliha- raan di Enrekang yang memiliki kondisi lingkungan dengan temperatur yang optimum untuk pemeliharaan ulat, hibrid Cina memperlihatkan persentase rata-rata rendemen pemeliharaan yang sedikit lebih tinggi dibanding hibrid lokal, meskipun secara statistik tidak berbeda nyata $(\mathrm{P}>0,05)$.

Kokon merupakan hasil akhir dari pemeliharaan ulat. Kualitas kokon ditentukan oleh sifat keturunan dari jenis ulat sutera dan kondisi lingkungan seperti keadaan selama pemeliharaan, pengokonan, dan lain-lain (Hussein et al., 2011b). Syarat kokon yang baik adalah sehat (tidak cacat), bersih (putih bersih), bagian dalam (pupa) tidak rusak atau hancur, bagian kulit kokon (lapisan serat-serat sutera) keras dan kalau ditekan sedikit berat. Beberapa paramater kualitas kokon berpengaruh terhadap kualitas bahan baku serat sutera penyusunnya dan sangat menentukan terhadap kualitas, kuantitas, dan efisiensi dalam proses reeling (Gowda \& Reddy, 2007). Ciri-ciri kokon, seperti bobot kokon, bobot kulit kokon, ratio kulit kokon, adalah parameter penentu yang secara ekonomi paling penting dalam budidaya ulat sutera (Mirhosseini et al., 2010). Perbedaan bentuk dan ukuran kokon akan menghasilkan ukuran serat sutera yang berbeda, termasuk kualitas benangnya. Takabayashi et al. (1997 dalam Gowda \& Reddy, 2007) menyatakan, proses reeling pada kokon dengan bentuk yang tidak teratur dan tidak seragam akan menghasilkan benang yang terputus-putus, sulit diurai, dan bahan baku sutera yang diperoleh cenderung kurang bagus dan sulit ditingkatkan kualitasnya.

Berdasarkan perbandingan kualitas kokon, hibrid lokal menunjukkan hasil yang lebih baik dari hibrid Cina untuk semua parameter yang diamati, baik di Enrekang yang berada di ketinggian optimum untuk pemeliharaan ulat sutera maupun di Soppeng yang berada di daerah dataran rendah. Kaomini (2002) menyatakan bahwa persentase kulit kokon yang diperoleh dari sebuah kokon tergantung pada jenis atau ras ulat sutera, besarnya kokon, dan kondisi pemeliharaan. Persentase kulit kokon hibrid di daerah tropis menurut Mah (1998) dan Atmosoedarjo et al. (2000) berkisar antara $18,0-22,0 \%$. Pada penelitian ini rata-rata persentase kulit kokon yang dihasilkan dari kedua hibrid masih berada pada kisaran yang disebut Mah (1998) dan Atmosoedarjo et al. (2000), bahkan hibrid lokal menghasilkan persentase yang lebih tinggi, baik pada pemeliharaan di Soppeng maupun Enrekang. 
Persentase kulit kokon adalah salah satu tolok ukur untuk penentuan harga jual kokon. Grade tertinggi (tingkatan kualitas kokon) adalah persentase kulit kokon sebesar 22-25 \% (Kim, 1998). Hasil penelitian menunjukkan hanya hibrid lokal yang dapat memenuhi standar Kim (1989) untuk persentase kulit kokon.

Hasil budidaya ulat sutera juga ditentukan oleh kualitas serat yang membungkus kokon. Kualitas serat sutera sangat penting dalam pemintalan karena akan mempengaruhi benang sutera yang diperoleh. Semakin baik kualitas serat yang akan dipintal maka benang sutera yang diperoleh juga akan semakin meningkat baik kualitas maupun kuantitasnya (Budisantoso, 1997). Kualitas tersebut mencakup bobot kokon kering, jumlah putus serat, sisa kokon, persentase bobot serat, dan reelability (daya urai serat). Reelability adalah kemampuan serat sutera untuk terurai dan tergulung pada saat kokon dipintal. Daya urai kokon sangat tergantung pada varietas ulat sutera, suhu dan kelembaban semasa pengokonan. Alat pengokonan juga berpengaruh terhadap daya urai kokon (Atmosoedarjo et al., 2000). Semakin tinggi daya gulung akan semakin efisien dalam proses pemintalan.

Hasil penelitian menunjukkan semua perlakuan memberikan perbedaan nyata pada beberapa parameter kualitas kokon yaitu panjang serat, bobot benang per 50 kokon, persentase serat dan reelability. Hasil analisis ragam menunjukkan hibrid lokal menghasilkan kualitas serat yang lebih baik dari hibrid Cina untuk semua paramater.

\section{KESIMPULAN DAN SARAN}

\section{A. Kesimpulan}

1. Masa larva hibrid Cina relatif lebih pendek dua hari dibandingkan hibrid lokal (dari Perum Perhutani Soppeng).

2. Persentase penetasan dan rendemen pemeliharaan hibrid Cina menunjukkan hasil yang tinggi $(90 \%)$ serta daya gulung lebih tinggi dibanding hibrid lokal yaitu rata-rata $90 \%$.

3. Kualitas kokon hibrid Lokal menunjukkan hasil yang lebih tinggi dibandingkan hibrid dari Cina.

4. Secara keseluruhan kualitas benang hibrid lokal lebih tinggi dari hibrid Cina.

\section{B. Saran}

1. Hasil uji adapatasi di dua lokasi Soppeng dan Enrekang, hibrid dari Cina dapat dijadikan hibrid alternatif untuk mendampingi hibrid lokal (dari Perum Perhutani Soppeng). Dari keseluruhan analisis kualitas kokon dan benang hibrid Cina cenderung lebih baik untuk dataran rendah. Hibrid Cina daya gulungnya tinggi jadi ada kemudahan dipintal dan hasil benangnya tinggi.

2. Untuk meningkatkan kualitas hibrid, hibrid Cina supaya dimurnikan kembali kemudian disilangkan dengan hibrid yang ada di koleksi Bank Plasma Ulat Sutera Balitbanghut Bogor yang memiliki kualitas tinggi tetapi kurang daya tahannya terhadap dataran rendah.

\section{DAFTAR PUSTAKA}

Atmosoedardjo, H.K., Kartasubrata, J., Kaomini, M., Saleh,W., \& Moerdoko,W. (2000). Sutera Alam Indonesia. Cetakan Pertama. Jakarta: Yayasan Sarana Wana Jaya.

Budisantoso, H. (1997). Pengaruh alat pengokonan dan teknik pemasakan kokon terhadap kualitas serat. Jurnal Penelitian Kehutanan 2 (4): 3045. Balai Penelitian Ujung Pandang, Makasar.

Choe Byong Hee. (nd). Sericulture technology. Seoul National University. Suwon. Korea.

ESCAP. (1993). Principles and techniques of silkworm breeding. New York: United Nations.

Gowda, B.N., \& Reddy, N.M. (2007). Influence of different environmental conditions on cocoon parameters and their effects for reeling performance of bivoltine hybrids of silkworm, Bombyx mori L. Int. J. Indust. Entomol, 14(1): 15-21.

Hussein, M., Naeem, M., Khan, S.A., Bhatti, M.F., \& Munawar, M. (2011a). Studies on the enfluance of temperature and humidity on biological traits of silkworm (Bombyx mori L. : Bombycidae). African J. Biotech. 10 (57): 12368-12375. Akses tanggal 29 September 2012, dari: http://academicjournals. org/AJB.

Hussain, M., Khan, S.A., Naeem, M., Aqil, T., Khursheed, R., \& ul Mohsin, A. (2011b). Evaluations of silkworm lines against variations in temperature and $\mathrm{RH}$ for various parameters of commercial cocoon production. Psyche vol. 2011, article ID 145640. Akses tanggal 29 September 2012, dari: http://www. hindawi.com/journals/psyche/2011/145640/. 
Kaomini, M. (2002). Pedoman teknis pemeliharaan ulat sutera. Bandung: Samba Project.

Kim, S.E. (1998). Silkworm breeding. In: Principles and Practices in Sericulture, NSERI. Korea.

Mah, Y.I. (1998). Silkworm rearing. In: Principles and practices in sericulture. National Sericulture and Entomology Research Institute. Republic of Korea.

Mattjik, A.A., \& Sumertajaya, I.M. (2002). Perancangan percobaan. Bogor: IPB Press.

Mirhosseini, S.Z., Nematollahian, S., Ghanipoor, M., \& Seidavi, A. (2010). Comparison of phenotypic and genetic permormance of local silkworm groups and two commercial lines. Biol. Res. 43:411-416.

Nezhad, M.S., Mirhosseini, S.Z., Gharahveysi, S., Mavvajpour, M., \& Seidavi, A.R. (2010). Performance of peanut cocoon strains of Iranian silkworm (Bombyx mori) germ-plasm with reference to reproductive characters. $J$. Food, Agriculture and Environment 8(3\&4): 1096-1101. WFL Publisher, Science and Technology. Akses tanggal 29 September 2012, dari: http://www.world-food.net.
Peraturan Menteri Kehutanan No. P-56/Menhut-II/ 2007 tentang Pengadaan dan Peredaran Telur Ulat Sutera, tanggal 7 Desember 2007.

Samsijah, \& Andadari, L. (1993). Perbandingan kualitas kokon dan serat beberapa persilangan ras ulat sutera (Bombyx mori L). Buletin Penlitian Hutan No. 556: 23-39. Pusat Penelitian dan Pengembangan Hutan dan Konservasi Alam. Bogor.

Saheb, N.M.B., \& P. Gowda. (1987). Silkworm seed technology. In Jolly, M.S. (ed.) Appropriate sericulture techniques. International Centre for Training and Research in Tropical Sericulture. Mysore, India.

Sadapotto, A. (2010). Penataan institusi untuk peningkatan kinerja persuteraan alam di Sulawesi Selatan: Studi Komparasi di Enrekang, Soppeng, dan Luoding City, Cina. (Tidak dipublikasikan) Disertasi. Sekolah Pascasarjana, Institut Pertanian Bogor. Bogor.

Seidavi, A. (2012). Study on thirty-one economically important traits in twenty silkworm Bombyx mori Varieties. African J. Biotechnology 11 (36): 8938-8947. 
Lampiran (Appendix) 1. Deskripsi hibrid Perhutani (Descriptions of Perhutani silkworm hibrid)

- Voltinisme (Voltinism)

- Asal hibrid(Hybrid origin)

- Corak ulat(Color oflarvae)

- Warna kokon (Cocoon color)

- Bentuk kokon(Cocoon shape)

- Masa larva(Larval period)

- Persentase penetasan (Egg hatchability)

- Kualitas kokon(Cocoon quality)

Kokon normal (Nourmal cocoon)

Bobot kokon (Cocoon weight)

Bobot kulit kokon (Shell weight)

Persentase kulit kokon (Shell ratio)

- Kualitas serat (Quality offilament)

Panjang filament (Filament length)

Persentase filament (Filament percentage) : $21 \%$

Ketebalan (fFilament thickness)

Daya urai (Reelability)
: bivoltine (bi-voltine)

: Perum Perhutani Soppeng

: $\operatorname{bintik}($ spotted)

: putih(white)

: lonjong (oval)

: Soppeng 22 hari (days)

Enrekang 28 hari (days)

: $81,65-81,95 \%$

: $86,75-93,25 \%$

: $1,70-2,04 \mathrm{~g}$

: $0,41-0,46 \mathrm{cg}$

: $22,30-23,97$

: $1026-1127 \mathrm{~m}$

: $2,71-3,63$

: $76-89 \%$

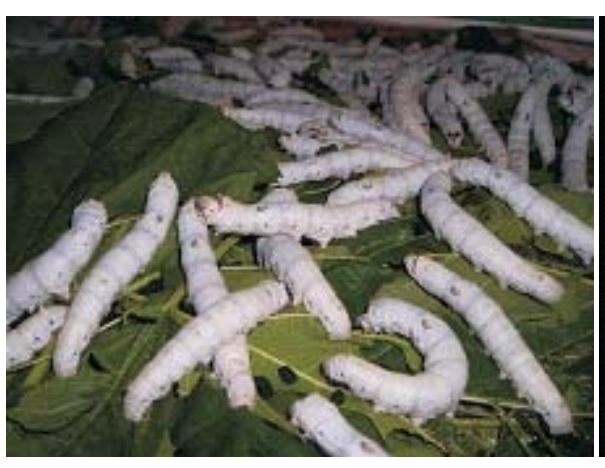

Larva

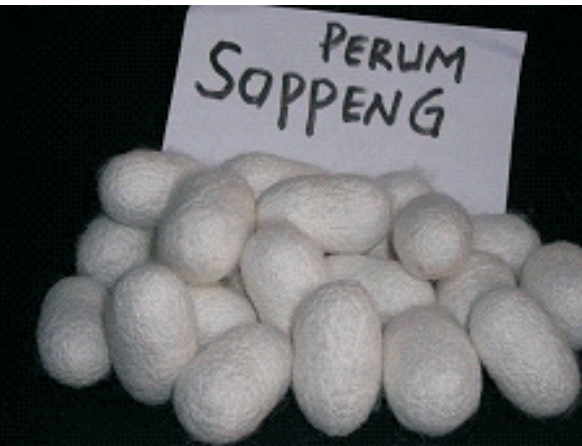

Kokon

Gambar(Figure) 2. Larva dan kokon hibrid Perhutani Soppeng (The larvae and the cocoon of Perhutani silkworm hibrid) 
Lampiran (Appendix) 2. Deskripsi hibrid China (Descriptions of Chinesse silkworm hibrid)

- Voltinisme (Voltinism)

- Asal hibrid (Hybrid origin)

- Corak ulat (Color of larvae)

- Warna kokon (Cocoon color)

- Bentuk kokon (Cocoon shape)

- Masa larva (Larval period)

- Persentase penetasan (Egg hatchability)

- Kualitas kokon (Cocoon quality)

Kokon normal (Nourmal cocoon)

Bobot kokon (Cocoon weight)

Bobot kulit kokon (Shell weight)

Persentase kulit kokon (Shell ratio)

- Kualitas serat (Quality of filament)

Panjang filament (Filament length)

Persentase serat (Filament percentage)

Ketebalan (Filament thickness)

Daya urai (Reelability)
: bivoltine (bi-voltine)

: Cina

: polos (plain)

: putih (white)

: lonjong (oval)

: Soppeng 20 hari (days)

Enrekang 26 hari (days)

: $90,27-91,10 \%$

: $80,08-90,08 \%$

: $1,44-1,57 \mathrm{~g}$

: $0,30-0,32 \mathrm{cg}$

: $19,76-20,96 \%$

: 889-994 m

: $17-19 \%$

: $2,37-2,97$

: $85-95 \%$

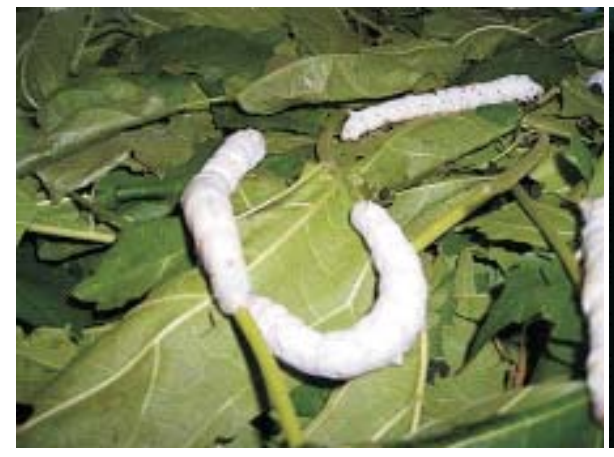

Larva

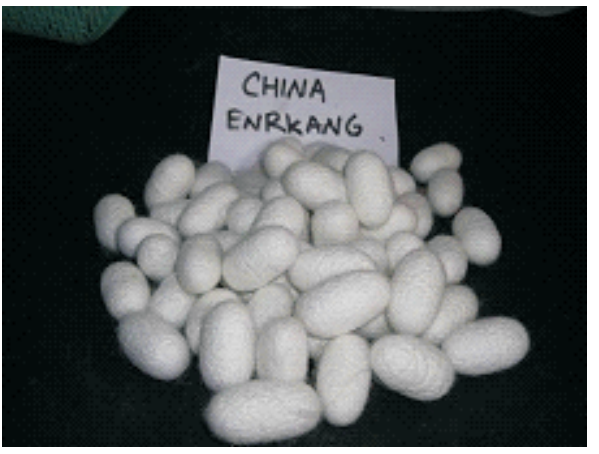

Kokon

Gambar(Figure) 3. Larva dan kokon hibrid Cina (The larvae and the cocoon of Chinesse silkworm hibrid) 